\title{
Genetic and pharmacologic manipulation of vacuolar ATPase: Effects on zymogen activation in pancreatic acini
}

This article was published in the following Dove Press journal:

Open Access Animal Physiology

18 November 2009

Number of times this article has been viewed

\author{
Thomas Kolodecik ${ }^{1,3}$ \\ Fred Gorelick ${ }^{1-3}$ \\ Edwin Thrower ${ }^{1,3}$ \\ 'Department of Internal Medicine, \\ Section of Digestive Diseases, \\ ${ }^{2}$ Department of Cell Biology, Yale \\ University School of Medicine, \\ New Haven, CT, USA; ${ }^{3}$ Veterans \\ Administration Connecticut \\ Healthcare, West Haven, CT, USA
}

Correspondence: Edwin CThrower Veterans Administration Medical Center, 950 Campbell Ave., Bldg. 4,West Haven, CT 06516, USA

Tel +I 203932 57II (ext. 3680)

$\mathrm{Fax}+\mathrm{I} 2039373852$

Email edwin.thrower@yale.edu

\begin{abstract}
Premature activation of inactive digestive enzymes (or zymogens) within the pancreatic acinar cell is an initiating event in acute pancreatitis (AP). We have found that this response depends on the assembly and activation of an adenosine triphosphate (ATP)-dependent proton pump, the vacuolar ATPase (vATPase). Previously, we have shown that the classic vATPase inhibitors concanamycin and bafilomycin can inhibit zymogen activation induced experimentally by high doses of the cholecystokinin orthologue, cerulein (CER) in isolated acinar cells. Recent studies have questioned the specificity of these inhibitors. In the current study we examine the role of the vATPase in pancreatitis using the newly developed novel vATPase inhibitors lobatomide-B and salicylihalamide-A as well as a genetic approach using siRNA. Both lobatomide-B and salicylihalamide-A inhibited CER-stimulated zymogen (trypsinogen and chymotrypsinogen) activation but had no effect on amylase secretion. Lobatomide-B $(0.1 \mu \mathrm{M})$ was more potent, reducing activation to baseline levels. Treatment of cells with siRNA specific for the vATPase E-subunit (V1E) significantly decreased V1E expression. V1E siRNA also significantly decreased chymotrypsinogen activation, but not amylase secretion. These studies confirm a role for the vATPase in zymogen activation and demonstrate that the novel and specific inhibitors lobatomide-B and salicylihalamide-A reduce early pancreatitis responses.
\end{abstract}

Keywords: lobatomide, salicylihalamide, cerulein, siRNA

\section{Introduction}

One of the earliest events in acute pancreatitis, an inflammatory condition of the pancreas, is the aberrant intracellular activation of zymogens within the pancreatic acinar cell. Evidence suggests that pancreatic zymogen activation depends on the generation of a low $\mathrm{pH}$ compartment. ${ }^{1}$ Our laboratory has shown that the proton pump, vacuolar adenosine triphosphatase (vATPase), is involved in pancreatic zymogen activation using the general vATPase inhibitors, bafilomycin-A1 and concanamycin-A. ${ }^{2}$ The vATPase is found ubiquitously in the membranes of eukaryotic cells and is a heteromultimeric protein complex consisting of a cytosolic V1 domain and a membranebound V0 domain. Assembly of the soluble V1 complex onto the membrane-bound V0 complex is required for proton pumping activity. ${ }^{3}$ Classically, the involvement of the vATPase in intracellular events has been determined using the plecomacrolide antibiotics bafilomycin and concanamycin as specific inhibitors of vATPase activity. The inhibitory effect of bafilomycin and concanamycin on vATPase activity is due to their binding to the c-subunit of the V0 complex. ${ }^{4,5}$ Recent studies have brought into question the specificity of these inhibitors for vATPase-dependent proton pumping activity. Teplova and colleagues examined the effects of bafilomycin on mitochondrial function submit your manuscript $\mid$ www.dovepress.com

Dovepress
Open Access Animal Physiology 2009: I I-II

(C) 2009 Kolodecik et al, publisher and licensee Dove Medical Press Ltd. This is an Open Access article which permits unrestricted noncommercial use, provided the original work is properly cited. 
and showed that it can function as a potassium ionophore. ${ }^{6}$ In RAW 264.7 cells bafilomycin and concanamycin both cause an increase in nitrite production, which is blocked by nitric oxide synthase (iNOS) inhibition. Bafilomycin causes the degradation of $\mathrm{I} \kappa \mathrm{B}$ and phosphorylation of JNK resulting in the activation of nuclear factor-kappaB (NF- $\mathrm{BB})$ and ultimately an increase in iNOS mRNA and protein. ${ }^{7}$ The method by which bafilomycin causes I $\mathrm{KB}$ degradation and JNK phosphorylation are unclear, but raise the possibility that these effects might not be related to vATPase inhibition. Bafilomycin ${ }^{8}$ and concanamycin ${ }^{9}$ have been shown to block chloroquine induced apoptosis in cultured cerebellar granule neurons at concentrations which do not inhibit vATPase activity ( $\leq 1 \mathrm{nM}$ ). This inhibition of chloroquine-induced apoptosis is seen with bafilomycin concentrations as high as $100 \mathrm{nM}$ but the effects are minimized due to bafilomycin's intrinsic stimulation of apoptosis. ${ }^{8}$ Together, these findings suggest that bafilomycin and concanamycin could have cellular effects unrelated to inhibition of the vATPase.

Another class of vATPase inhibitors are the benzolactone enamides which are specific for the inhibition of vATPases from higher vertebrates. ${ }^{4,10,11}$ This class of inhibitors includes the lobatomides and salicylihalamides, which were isolated from the marine tunicate worm ${ }^{12}$ and marine sponge, ${ }^{13}$ respectively and were originally identified as antitumor compounds. ${ }^{10}$ Salicylihalamides bind to the V0 complex of the mammalian vATPase and this binding is distinct from the binding site for bafilomycin ${ }^{14}$ and concanamycin. ${ }^{4}$

In a previous study we showed that treatment of pancreatic acinar cells with bafilomycin or concanamycin blocked cerulein (CER)-induced zymogen activation. ${ }^{2}$ Because these compounds have been recently reported to affect vATPaseindependent responses, the goal of the present study was to confirm the role of the vATPase in zymogen activation using a new class of pharmacologic inhibitors and genetic knockdown of vATPase. Using these approaches, we have confirmed a role for vATPase activity in secretagoguestimulated zymogen activation.

\section{Material and methods Isolation of pancreatic acinar cells}

All experiments and procedures using rats were performed in accordance with a protocol approved by the Veteran's Administration Institutional Animal Care and Use Committee (West Haven, CT). Pancreatic acinar cells were isolated as previously described. ${ }^{15}$ Briefly, fasted male Sprague-Dawley rats 100-150 g (Charles River Laboratories, Wilmington, $\mathrm{MA}$ ) were euthanized by $\mathrm{CO}_{2}$ inhalation. The pancreas was collected in buffer A: (10 mM Hepes [pH 7.4], $95 \mathrm{mM} \mathrm{NaCl}$, $4.7 \mathrm{mM} \mathrm{KCl}, 0.6 \mathrm{mM} \mathrm{MgCl}, 1 \mathrm{mM} \mathrm{NaH} \mathrm{PO}_{4}, 10 \mathrm{mM}$ glucose, $2 \mathrm{mM}$ glutamine, plus $0.1 \%$ bovine serum albumin, $1 \times$ MEM-amino acids (GIBCO-BRL, San Jose, CA]). The pancreas was then minced in $5 \mathrm{ml}$ of buffer $\mathrm{A}$ and washed $2 \mathrm{x}$ with $5 \mathrm{ml}$ of buffer $\mathrm{A}$, then transferred to $12 \mathrm{ml}$ of buffer-B (buffer-A $+1.3 \mathrm{mM} \mathrm{CaCl}$ ) with $50 \mathrm{U} / \mathrm{ml}$ of type- 4 collagenase (Worthington, Freehold, NJ). After incubation for one hour at $37^{\circ} \mathrm{C}$ with shaking (120 rpm) under constant $\mathrm{O}_{2}$, the preparation was filtered through a $300-400 \mu \mathrm{m}$ mesh (Sefar American, Depew, NY). The flow-through from the mesh was gravity pelleted and washed $2 \mathrm{x}$ with $12 \mathrm{ml}$ of buffer $\mathrm{B}$. The resulting acini were suspended in buffer $B$ and plated at $0.5 \mathrm{ml}$ of cells per well in a 24-well Falcon tissue culture plate.

\section{Treatment of acinar cells with vATPase inhibitors}

The tissue culture plate containing pancreatic acini were placed in an incubation chamber and allowed to recover for one hour at $37^{\circ} \mathrm{C}$ with shaking $(90 \mathrm{rpm})$ under constant $\mathrm{O}_{2}$. At one hour, cells were removed from the chamber and the media exchanged for $0.5 \mathrm{ml}$ of new buffer-B. At this time the vATPase inhibitors lobatomide-B, salicylihalamide-A $(0.01-1 \mu \mathrm{M})$ (Both inhibitors were provided by the Technology Transfer Branch of the NCI, CRADA; http:/www-otd.nci.nih.gov/cradaopp.html) or the drug vehicle $(0.1 \% \mathrm{DMSO})$ were added one hour prior to other treatments. After an hour CER was added to the appropriate wells at a final concentration of $100 \mathrm{nM}$ and incubated for one hour. After one hour of CER treatment the contents of the wells were transferred to $1.5 \mathrm{ml}$ eppendorf tubes and centrifuged $30 \times \mathrm{g}$ for one minute. After centrifugation, $50 \mu \mathrm{l}$ of cell-free media was removed to assay for amylase secretion. The tubes containing the cell pellets and remaining media as well as those containing media alone were stored at $-80{ }^{\circ} \mathrm{C}$ until used for the determination of zymogen activation and amylase secretion.

\section{Treatment of acinar cells with siRNA}

Pancreatic acini were isolated as above. Both control siRNA (Cat\# SI02020076; Qiagen, Valencia, CA) and vATPase E-subunit siRNA (Cat\# SI02020039; Qiagen) were prepared as follows: jetPEI (Qbiogene, Wiesbaden, Germany) was diluted $1 \mu \mathrm{l} / 100 \mu \mathrm{l}$ in $150 \mathrm{mM} \mathrm{NaCl} \mathrm{pH}$ 7.4. jetPEI was further diluted $8.9 \mu \mathrm{l} / 25 \mu \mathrm{l} / 40 \mathrm{pMoles}$ of siRNA to be added. siRNA was diluted to a final concentration of 40-80 pMoles in a final volume of $25 \mu \mathrm{l}$ using $150 \mathrm{mM} \mathrm{NaCl} \mathrm{pH} \mathrm{7.4.}$ siRNA was vortexed and allowed to sit for 10 minures. $25 \mu \mathrm{l}$ of appropriately diluted jetPEI was combined with $25 \mu \mathrm{l}$ 
of corresponding siRNA and vortexed. After vortexing the siRNA/JetPEI was allowed to sit for 60 minutes before being added $(50 \mu \mathrm{l} /$ well $)$ to the cells. At the same time as the siRNA addition, carbachol ( $1 \mu \mathrm{M}$ final) was added to all wells to stimulate uptake of siRNA by endocytosis. ${ }^{16,17}$ After 30 minutes of carbachol treatment $1 \mu \mathrm{M}$ atropine was added to block any further carbachol effects. Cells were incubated for an additional 2.5 hours to allow for siRNA-dependent protein knockdown. CER (100 nM) or medium was added for one hour. After one hour of CER treatment, cells were collected and processed for zymogen activation and amylase secretion or to assess vATPase E-subunit protein levels by immunoblot.

\section{Inhibition of new protein synthesis}

Tissue culture plates containing pancreatic acini were placed in an incubation chamber and allowed to recover for one hour at $37^{\circ} \mathrm{C}$ with shaking $(90 \mathrm{rpm})$ under constant $\mathrm{O}_{2}$. After an hour cells were removed from the chamber and the media exchanged for $0.5 \mathrm{ml}$ of new buffer-B. To inhibit protein synthesis, acini were treated with $300 \mu \mathrm{M}$ cyclohexamide for 30 minutes. Cells were then collected and centrifuged at $30 \times \mathrm{g}$ for one minute and cell pellet collected and further processed for immunoblot.

\section{Fluorescent zymogen assay}

Fluorescent zymogen assays were carried out as described. ${ }^{18}$ In brief, samples were thawed, homogenized, and centrifuged at $1000 \mathrm{~g}$ for one minute. To each well of a 24-well Falcon tissue culture plate, the following were added: $100 \mu \mathrm{l}$ of supernatant and $350 \mu \mathrm{l}$ of trypsin assay buffer $(50 \mathrm{mM}$ Tris [pH 8.1], $150 \mathrm{mM} \mathrm{NaCl}, 1 \mathrm{mM} \mathrm{CaCl}, 0.01 \%$ BSA). The assay was initiated by the addition of $50 \mu \mathrm{l}$ of $400 \mu \mathrm{M}$ enzyme substrate (fluorometric trypsin substrate; Peptides International, Louisville, KY) or fluorometric chymotrypsin substrate (Calbiochem, San Diego, CA). Enzyme activity was measured using a fluorometric microtiter plate reader (model HTS 7000; Perkin-Elmer Analytical Instruments, Shelton, CT; 380-nm excitation; 440-nm emission; 20 reads/10 minutes). Enzyme activity was normalized to total amylase content.

\section{Amylase secretion assay}

Amylase was assayed using a commercial kit (Phadebas Kit; Mangle Life Sciences, Lund, Sweden) as described. ${ }^{18}$ Amylase secretion into the media was expressed as percent of total amylase (media/[media + cells $]$ ).

\section{Immunoblot analysis}

Protein in cell pellets was solubilized by adding SDS-page loading buffer $(120 \mu \mathrm{l})$ and heating at $95{ }^{\circ} \mathrm{C}$. Proteins were separated on 10\% SDS-PAGE gels (Bio-Rad, Hercules, CA) and transferred to Immobilon-P membranes (Millipore, Billerica, MA). Membranes were blocked for $60 \mathrm{~min}$ at room temperature with Blotto (Tris-buffered saline [TBS], 5\% nonfat dry milk, $0.05 \%$ Tween-20). Membranes were then probed with primary antibody (rabbit anti-vATPase Esubunit, 1:500; Santa Cruz Biotechnology, Santa Cruz, CA) in Blotto for 60 minutes at room temperature, washed three times with blotto, and incubated with horseradish peroxidaseconjugated goat anti-rabbit immunoglobulin G (1:2000; Sigma, St. Loius, MO) for 60 minutes at room temperature. Membranes were washed three times in TBS, and protein bands were detected using a SuperSignal West pico chemiluminescence kit (Pierce Biotechnology, Rockford, IL).

\section{Cell morphology}

Cells were isolated as above and treated with or without vATPase inhibitors (concanamycin $100 \mathrm{nM}$, lobatomide-B $1 \mu \mathrm{M}$ or salicylihalamide-A $1 \mu \mathrm{M}$ ) for one hour followed by CER $100 \mathrm{nM}$ for an additional hour. Cells were centrifuged at $30 \times \mathrm{g}$ for five minutes and media was removed. To the cell pellets was added $1 \mathrm{ml}$ of PLP fixative $\left(10 \mathrm{mM} \mathrm{NaIO}_{4}\right.$, $75 \mathrm{mM}$ Lysine, $37.5 \mathrm{mM} \mathrm{NaPO}_{4}, 2 \%$ paraformldehyde) and placed on ice for one hour. Pellets were then washed two times with phosphate-buffered saline and postfixed in $1.0 \%$ osmium tetroxide (Polysciences, Inc, Warrington, PA), dehydrated in ethanol in propylene oxide, embedded in 100\% EPON resin, and sectioned using an ultramicrotome and then stained using hematoxylin. Sections were examined for cytosolic vacuole formation and plasma membrane blebbing using an Olympus $\mathrm{B} \times 51$ microscope.

\section{Statistical analysis}

Data represents mean \pm standard error of mean of at least three individual experiments unless otherwise noted, with each experiment being performed in at least duplicate. Student's $t$-test analysis was used to determine statistical significance and $P$ values of $<0.05$ were assigned significance.

\section{Results}

\section{Benzolactone enamide vATPase inhibitors abrogate CER-stimulated zymogen activation}

We first examined the effects of the benzolactone enamide vATPase inhibitors lobatomide-B and salicylihalamide-A on CER-induced zymogen (trypsinogen and chymotrypsinogen) activation and amylase secretion in isolated pancreatic acini. 
Trypsin and chymotrypsin activity were measured as markers for zymogen activation. Lobatomide-B was the more potent inhibitor, inhibiting both trypsinogen (Figure 1A) and chymotrypsinogen (Figure 1B) activation to control levels at concentrations of 0.1 and $1 \mu \mathrm{M}$. Salicylihalamide-A inhibited trypsinogen activation (Figure $1 \mathrm{~A}$ ) in a concentrationdependent manner, reaching significance at $1 \mu \mathrm{M}$ but had no effect on chymotrypsinogen activation (Figure- 1B). Neither inhibitor had any significant effect on CER-stimulated amylase secretion (Figure 2).

\section{siRNA dependent knockdown of $V, E$-subunit protein expression}

Most experiments utilizing siRNA are conducted for time periods exceeding 48 hours. Given this caveat, siRNA use in long term acinar cell cultures could prove problematic. Thus, it has been shown that in both rat $^{19}$ and mouse ${ }^{20}$ acinar cells, cellular responses to secretagogues change with time. For example, significantly higher concentrations of cholecystokinin are required to stimulate amylase secretion in acini maintained in culture overnight. ${ }^{19}$ When human pancreatic acinar cells are placed into long term culture and stained for amylase content half of the amylase immunoreactivity is lost by day 2 , with no immunoreactivity by day 4 . In contrast within two days $20 \%-50 \%$ of cells are positive for the duct cell markers keratin-19 and CAM 17.1 (a mucin antigen) and by day 5 almost $100 \%$ of cells are positive for these markers. ${ }^{21}$ This suggests that acinar cells in culture rapidly differentiate into a ductal cell type. Furthermore, zymogen activation is optimally examined in preparations of less than six hours and has not been detected in secretagogoue-stimulated acinar cells under long-term culture conditions. Our laboratory has found that acinar cells cultured for 12 hours or more no longer exhibit a zymogen activation response (unpublished data). To determine whether vATPase proteins could be depleted in an appropriate time frame using siRNA, we first investigated the half-life of an essential vATPase protein, the V1 E subunit. ${ }^{22}$ After acini were treated with $300 \mu \mathrm{M}$ cyclohexamide for 30 minutes to inhibit protein synthesis, the levels of the V1E protein were reduced by $60 \%$ (Figure 3 ). These results indicate that the $\mathrm{V} 1 \mathrm{E}$ protein has a high turnover rate and that it might be susceptible to siRNA in a short time-frame. To further enhance siRNA uptake, cells were treated with low levels of carbachol to stimulate siRNA endocytosis ${ }^{16,17}$ for 30 minutes. This was followed by a 2.5 hour time period to allow for protein knock down. Control siRNA had no effect on V1E levels while siRNA specific for the V1E knocked down protein levels to $15 \%$ of control (Figure 4 ).

\section{siRNA-dependent inhibition of CER-stimulated zymogen activation and secretion}

Next we determined if V1E-specific siRNA could reduce CER-stimulated zymogen activation and amylase secretion. V1E-specific siRNA had no significant effect on trypsinogen activation (Figure 5A) but dose-dependently inhibited chymotrypsinogen activation (Figure 5B). Control siRNA had no significant effect on zymogen activation (Figure 5A, 5B). Both control and V1E-specific siRNA caused a minor decrease in CER-stimulated amylase secretion (Figure 6) but this was not statistically significant.

\section{Effects of vATPase inhibition on CER-stimulated acinar cell morphology}

We also examined the effect of vATPase inhibitors on CER-stimulated changes in cell morphology. Untreated cells showed none of the hallmark indicators of cell injury (Figure 7A). Cells treated with CER 100 nM (Figure 7B) showed both plasma membrane blebbing (arrows) as well as the formation of cytosolic vacuoles (arrow heads). Preincubation with the vATPase inhibitors concanamycin (Figure 7C), lobatomide (Figure 7D), or salacylahalamide (Figure 7E) prior to CER stimulation had no effect on CER-stimulated membrane blebbing and cytosolic vacuole formation.

\section{Discussion}

Premature intracellular activation of pancreatic zymogens is a key event in the onset of pancreatitis. Our laboratory has shown that reducing extracellular or intracellular $\mathrm{pH}$ enhances secretagogue stimulated zymogen activation both in vitro and in vivo. ${ }^{23}$ In addition, the lysosomal hydrolase cathepsin-B has been shown to activate trypsinogen ${ }^{24,25}$ and this activation requires a low $\mathrm{pH}$ environment. ${ }^{26}$ Furthermore, cathepsins have been shown to colocalize with digestive zymogens ${ }^{27,28}$ and the zymogen activation compartment may be lysosomally derived and/or associated with the secretory pathway. ${ }^{29-31}$

The vATPase is associated with the regulation of $\mathrm{pH}$ in lysosome-related vesicles as well as other compartments. In addition to its association with intracellular compartments the vATPase has also been shown to be associated with the plasma membrane. In osteoclasts the plasma membranebound vATPase secretes hydrogen ions resulting in bone resorption. To date the potential role of proton extrusion by plasma membrane-associated vATPase on pancreatic acinar cell pathology has not been addressed. In pancreatic 
A



B

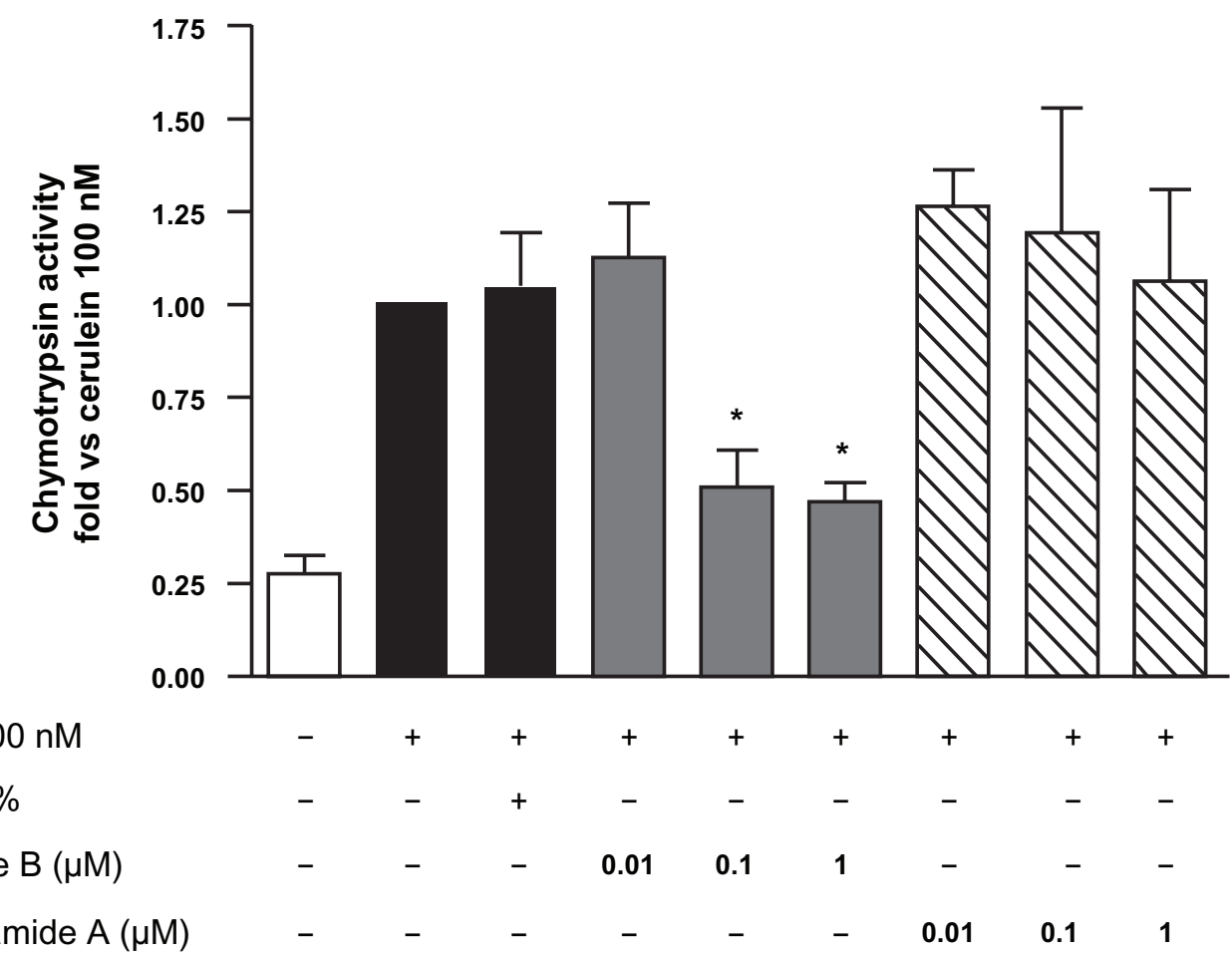

Figure I Lobatomide-B and salicylihalamide-A inhibit cerulein-induced zymogen activation. Acini were pretreated with lobatomide-B, salicylihalamide-A (0.0I-I $\mu$ M), or carrier $(0.1 \% \mathrm{DMSO})$ for one hour. Cerulein $100 \mathrm{nM}$ was then added to the appropriate wells and acini incubated for one hour. Samples were assayed for trypsin and chymotrypsin activity. Results are expressed as fold vs. cerulein $100 \mathrm{nM}$. All samples represent the mean \pm SEM of at least three experiments. $* P \leq 0.05$ vs cerulein $100 \mathrm{nM}$. Abbreviation: DMSO, dimethyl sulfoxide. 


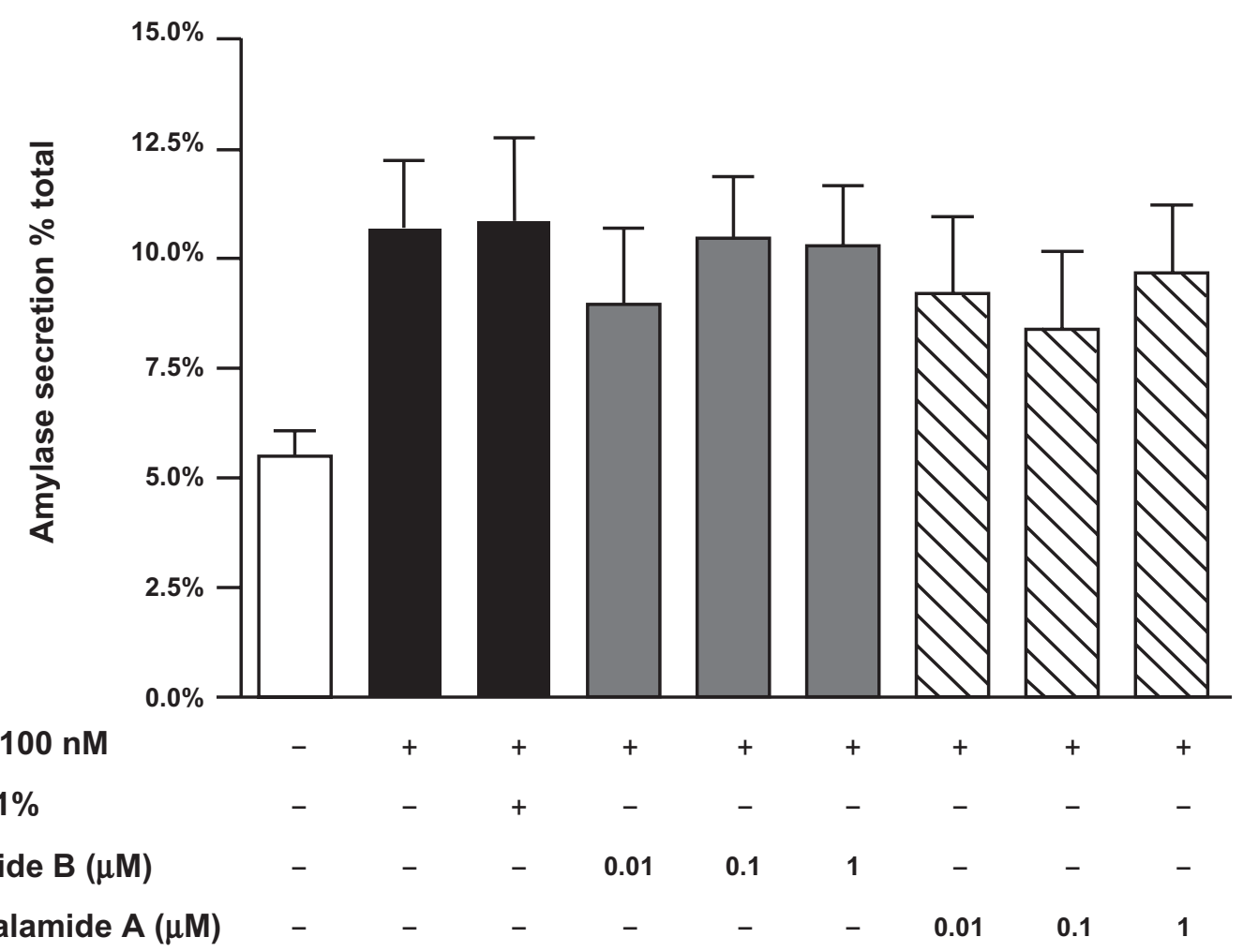

Figure 2 Lobatomide-B and salicylihalamide-A have no effect on cerulein-induced amylase secretion. Acini were pretreated with lobatomide-B, salicylihalamide-A (0.0I-I $\mu \mathrm{M})$, or carrier $(0.1 \%$ DMSO) for one hour. Cerulein $100 \mathrm{nM}$ was then added to the appropriate wells and acini incubated for one hour. Samples were assayed for secreted and total amylase activity; Results are expressed as amylase secretion as a \% of total amylase.All samples represent the mean \pm SEM of at least three experiments.

Abbreviations: DMSO, dimethyl sulfoxide; SEM, standard error of mean.

acinar cells CER stimulation leads to a translocation of soluble V1 subunits to membrane-associated compartments. ${ }^{2}$ Inhibition of vATPase with the classic vATPase inhibitors bafilomycin-A1 and concanamycin-A not only inhibits CER-stimulated zymogen activation, ${ }^{2}$ but also blocks the enhancing effect of an extracellular acid load in vitro. ${ }^{23}$ Because the classic vATPase inhibitors bafilomycin and concanamycin have been shown to have nonspecific effects, ${ }^{6-9}$ the current study was undertaken to confirm our previous results utilizing the novel class of vATPase inhibitors, the benzolactone enamides, which have a different mode of inhibition, as well as genetic manipulation using siRNA.

The benzolactone enamide vATPase inhibitors lobatomide and salicylihalamide were originally isolated from marine organisms ${ }^{12,13}$ and are specific for the inhibition of vATPases from higher eukaryotes. ${ }^{4,10,11}$ Like bafilomycin and concanamycin, lobatomide-B almost completely inhibited trypsinogen (Figure 1A) and chymotrypsinogen (Figure 1B) activation at concentrations equal to or greater than $100 \mathrm{nM}$. Salicylihalamide-A was not as potent causing inhibition to basal for trypsinogen activation (Figure 1A) at $1 \mu \mathrm{M}$ but had no significant effect on chymotrypsinogen activation (Figure 1B).
Like bafilomycin and concanamycin neither lobatomide-B nor salicylihalamide-A had a significant effect on amylase secretion (Figure 2). Salicylihalamide has been shown to bind to the V0 complex of the vATPase. Its primary effect on the assembled and active pump complex is the inhibition of proton translocation, a consequence of which is an inhibition of ATP hydrolysis by the V1 complex. ${ }^{14}$ However the ATP hydrolysis of the uncoupled V-ATPase or the isolated V1 complex is not affected. ${ }^{14}$ Furthermore, it has been shown that both bafilomycin and concanamycin block J-concanalid A binding to the vATPase V0 c-subunit while salicylihalamide does not block this interaction. ${ }^{4}$ These data suggest that the binding site for salicylihalamide on the V0 complex is not the same as that for bafilomycin and concanamycin on the c-subunit but does not rule out an alternate binding site on this subunit. The effects of lobatomide and salicylihalamide on zymogen activation confirm our previous results. ${ }^{2}$ The differences we observed in the potency of salicylihalamide and lobatomide on zymogen activation are consistent with those described by Boyd and colleagues ${ }^{10}$ where salicylihalamide-A was a more potent inhibitor of vATPase activity in isolated membrane preparations than lobatomides A-F, but was much less potent 

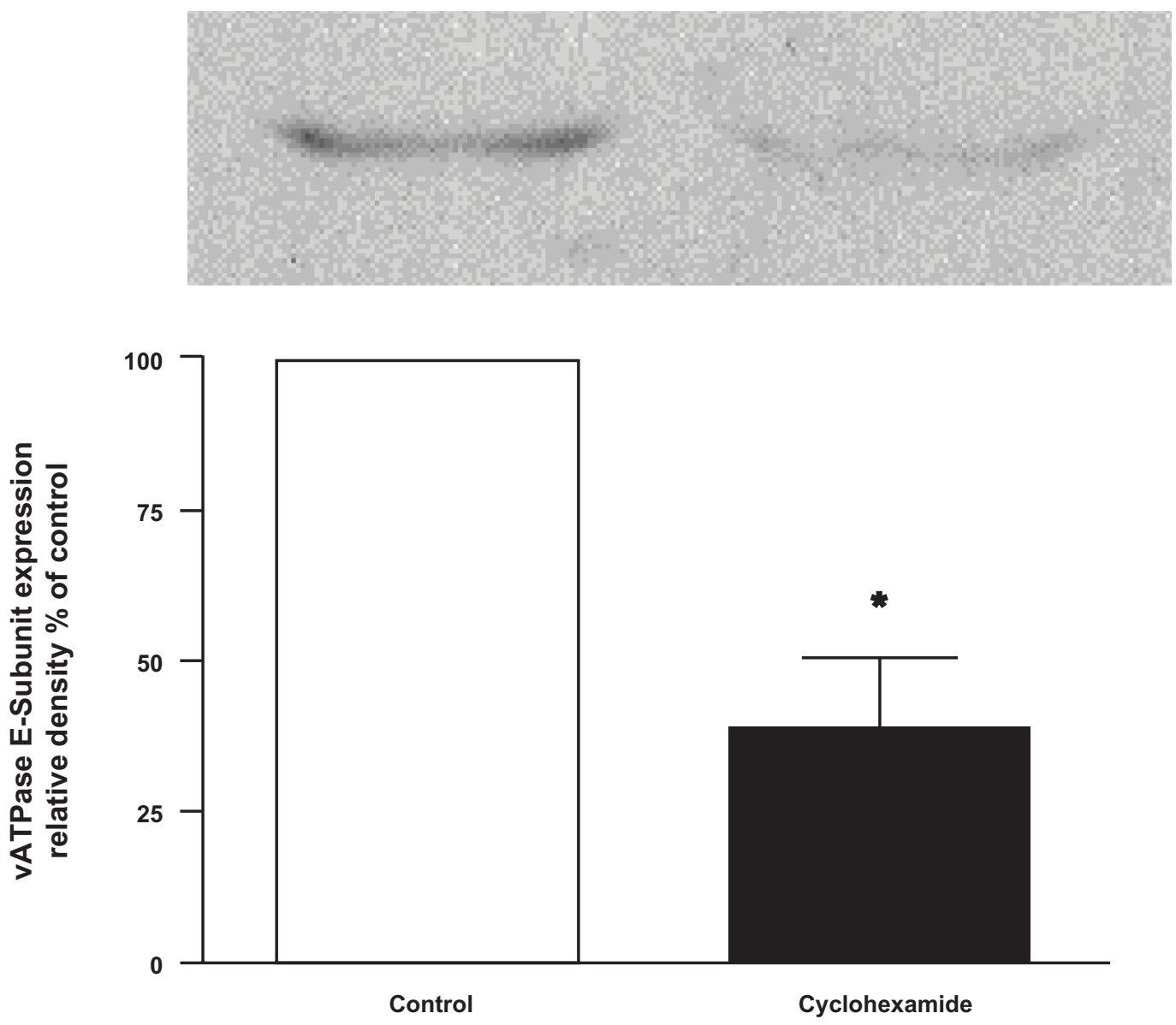

Figure 3 Inhibition of new protein synthesis knocks down vATPase E - subunit protein. Acini were treated with cyclohexamide ( $300 \mu \mathrm{M})$ for 30 minutes. Acini were collected by centrifugation, solubilized and subjected to western blot analysis. All samples represent the mean \pm SEM of at least three experiments. ${ }^{*} P \leq 0.05$ vs control (no cyclohexamide). The western blot is representative of one experiment.

than lobatomide-A in its ability to inhibit cell growth in oncogene transformed cell lines.

Since all pharmacological inhibitors have potential nonspecific effects we also used a complementary genetic approach. Using siRNA specific for V1E to knockdown protein expression we then examined the effects on CER-stimulated zymogen activation and amylase secretion. One of the major drawbacks of the use of siRNA in primary acinar cell culture is the time needed to affect a sufficient knockdown of protein content. Secretagogue stimulation does not reliably cause zymogen activation in acinar cells placed in culture for periods over six hours after isolation. Here we demonstrate that there is a rapid turnover of the V1E protein (Figure 3 ) and that siRNA specific for V1E can significantly knockdown V1E protein $(\sim 85 \%)$ within three hours (Figure 4). When we examined zymogen activation there was a significant inhibition of chymotrypsinogen activation (Figure 5B), but not trypsinogen activation (Figure 5A). Amylase secretion was reduced with both control siRNA and V1E siRNA but this decrease in amylase secretion was not statistically significant.

When vATPase inhibitors were used, an inhibition of activation of both zymogens was seen, but when siRNA specific to the V1E subunit was used there was only a knockdown of chymotrypsinogen activation. This difference between trypsinogen and chymotrypsinogen activation was unexpected but not unprecedented. Previous studies from our laboratory have shown that trypsinogen and chymotrypsinogen activation respond differently to various enzyme activators and inhibitors. In a reconstituted cell system it was shown that chymotrypsinogen activation was ATP-dependent, inhibited by the broad-spectrum kinase inhibitor (at $\mu \mathrm{M}$ concentrations) H-89, but unaffected by the cathepsin-B inhibitor E64-d. Trypsinogen activation, on the other hand, was shown to be independent of ATP, inhibited by E64-d and unaffected by H-89.32 In whole cell culture chymotrypsinogen activation was more sensitive to the inhibition of PKC than trypsinogen activation. ${ }^{33}$ These data suggest that the activation of the 

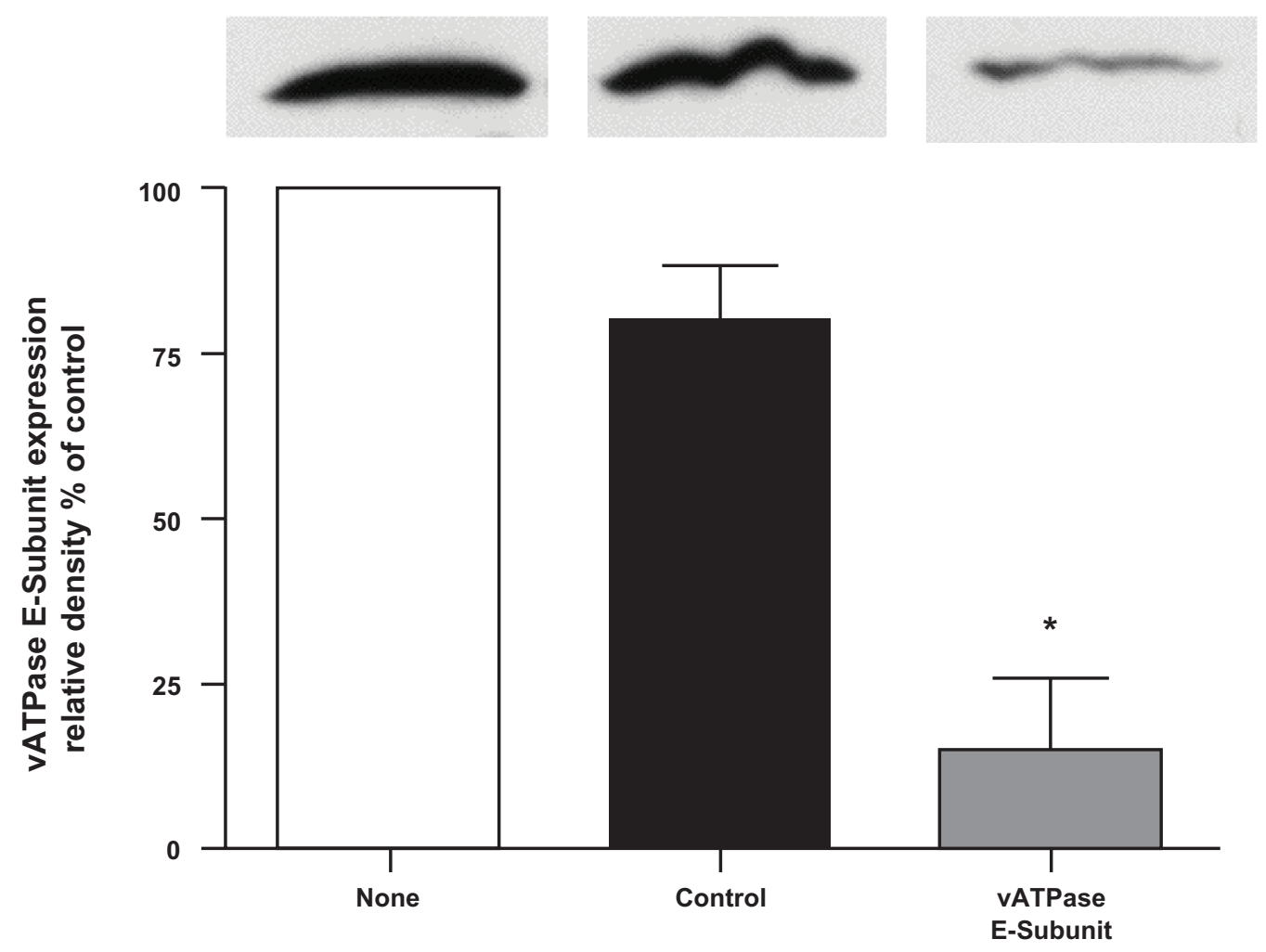

SiRNA [40 pMoles]

Figure 4 siRNA specific for vATPase V,E-subunit knocks down VIE protein content in acini. Acini were incubated with control and E-subunit-specific siRNA in the presence of carbachol $(I \mu M)$ for 30 minutes to stimulate uptake. The effects of carbachol were neutralized by atropine treatment (I $\mu M)$. Acini were further incubated for 2.5 hours to accomplish protein knockdown. Acini were collected by centrifugation solubilized and subjected to western blot analysis. All samples represent the mean \pm SEM of at least three experiments. ${ }^{*} P \leq 0.05$ vs no siRNA. The western blot is representative of one experiment.

Abbreviation: SEM, standard error of mean.

zymogens trypsinogen and chymotrypsinogen may be via different cellular pathways. Preliminary studies from our laboratory suggest that secretagogue stimulation results in the activation of trypsinogen and chymotrypsinogen in distinct cellular compartments (Shugrue, unpublished observations) and our current data supports this possibility.

The siRNA knockdown lowered V1E protein levels but this resulted in only a marginal effect on trypsinogen activation as mentioned above. A number of reasons could account for this result. The compartment(s) in which zymogen activation occurs may have a significant number of V1/V0 complexes already assembled and functional; a short-term knockdown may not result in a noticeable effect on intra-compartmental $\mathrm{pH}$. Additionally, these functional V1/V0 complexes may be preferentially located on trypsinogen-only containing compartments. Another factor could be that the siRNA knockdown of V1E was incomplete, reducing protein levels but not eliminating them completely. Perhaps the few remaining assembled V1/V0 complexes are able to compensate for less available functional V1 complexes and upregulate their activity.
When morphology was examined we found that inhibition of the vATPase with concanamycin-A, lobatomide-B or salicylihalamide-A did not reduce CER (100 nM)-stimulated vacuole formation or membrane blebbing (Figure 7). These finding suggest that these morphologic changes associated with acinar cell injury might not be related to vATPase or zymogen activation. ${ }^{34}$ Thus, it is possible that factors such as NFKB, or changes in either cytosolic calcium or cAMP associated with CER stimulation could be vATPase-independent and relate to these morphologic changes. In this study we show that inhibition of the vATPase has no effect on CER-stimulated amylase secretion, suggesting that the inhibitors do not have nonselective effects on acinar cell responses (Figure 2).

In conclusion this study confirms a role for the vATPase in secretagogue-stimulated zymogen activation. We also show that proteins with a rapid turnover rate can be knocked down in a timeframe in which zymogen activation can still be assessed. Lastly, we have provided evidence that trypsinogen and chymotrypsinogen activation may be differentially regulated. 
A

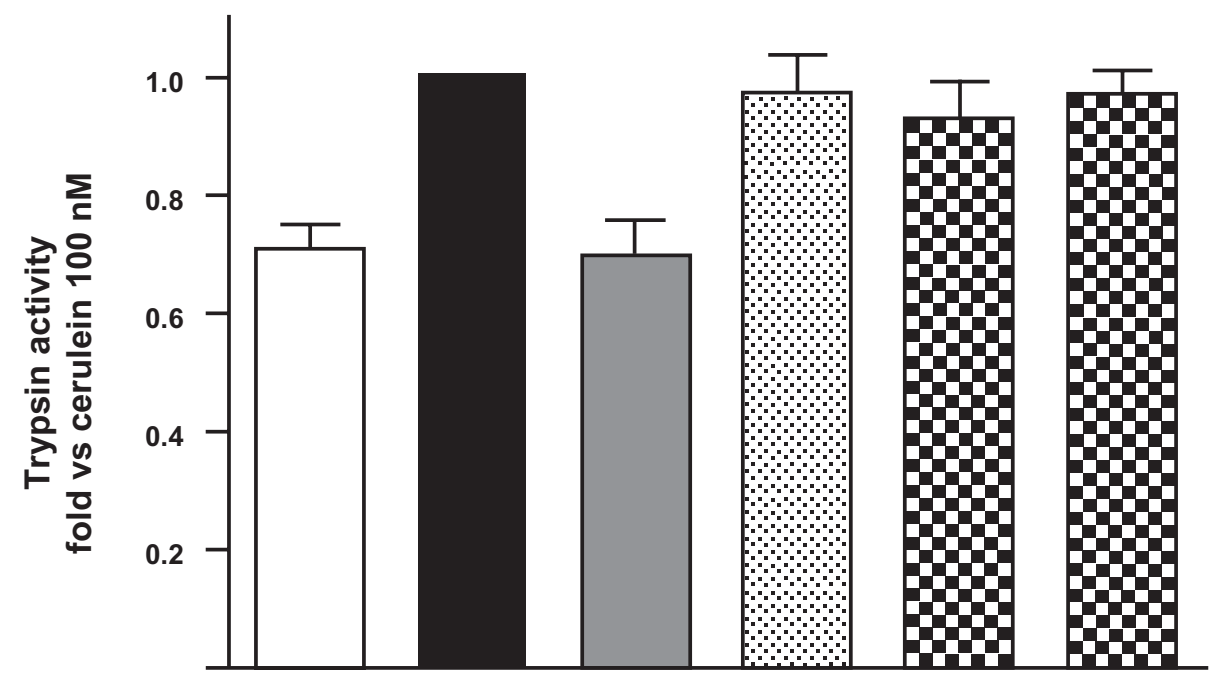

Cerulein $100 \mathrm{nM}$

Control siRNA 40 pMoles

vATPase siRNA 40 pMoles

vATPase siRNA 80 pMoles

B

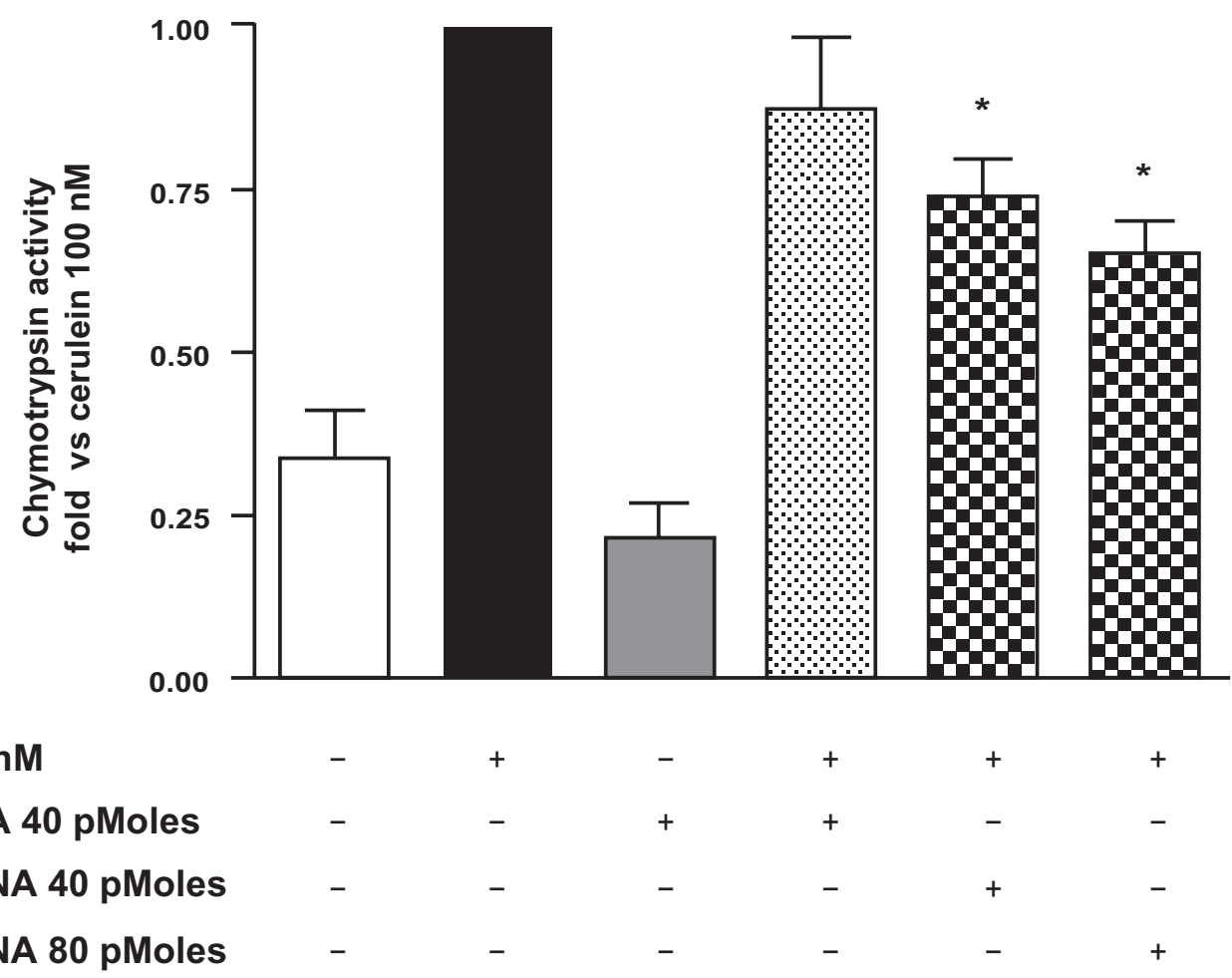

Figure 5 siRNA specific for vATPase $V_{1} E$-subunit inhibits chymotrypsin but not trypsin activation. Acini were incubated with control and E-subunit-specific siRNA in the presence of carbachol $(I \mu M)$ for 30 minutes to stimulate uptake. The effects of carbachol were neutralized by atropine treatment $(I \mu M)$. Acini were further incubated for 2.5 hours to accomplish protein knockdown. Cerulein was then added to the appropriate wells for one hour. Samples were assayed for trypsin and chymotrypsin activity. Results are expressed as fold vs cerulein $100 \mathrm{nM}$. All samples represent the mean \pm SEM of at least three experiments. ${ }^{* P} \leq 0.05$ vs cerulein $100 \mathrm{nM}$. Abbreviation: SEM, standard error of mean. 




Figure 6 siRNA knockdown of $v A T P a s e V, E$-subunit has no significant effect on cerulein-stimulated amylase secretion. Acini were incubated with control and E-subunit-specific siRNA in the presence of carbachol $(I \mu M)$ for 30 minutes to stimulate uptake. The effects of carbachol were neutralized by atropine treatment ( $\mu M$ ). Acini were further incubated for 2.5 hours to accomplish protein knockdown. Cerulein was then added to the appropriate wells for one hour. Samples were assayed for secreted and total amylase activity. Results are expressed as amylase secretion as a \% of total amylase. All samples represent the mean \pm SEM of at least three experiments.

Abbreviation: SEM, standard error of mean.
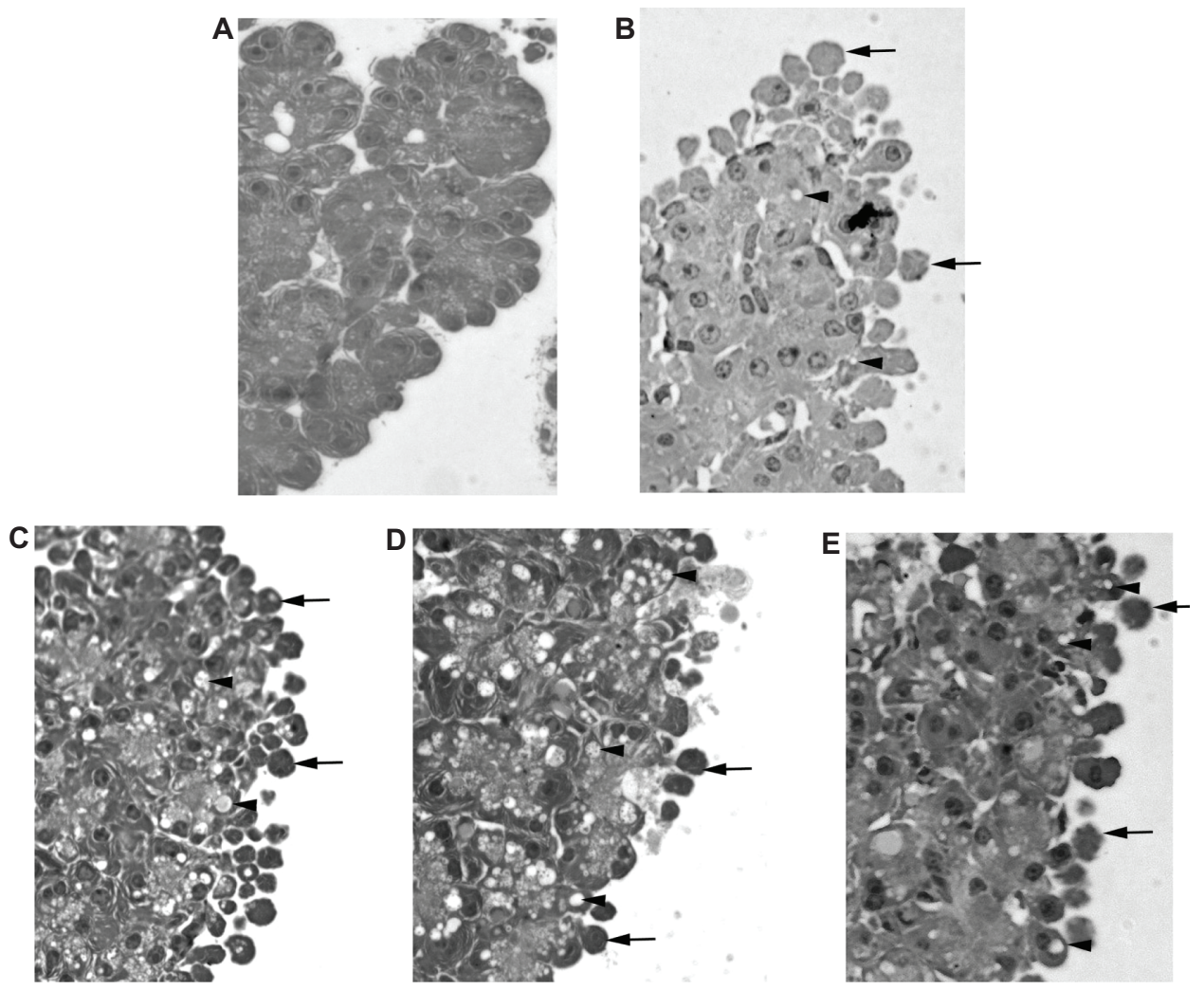

Figure 7 vATPase inhibition does not affect cerulein $100 \mathrm{nM}$-dependent changes in cell morphology. Acini were incubated with the vATPase inhibitors concanamycin-A $(\mathrm{I} 00 \mathrm{nM})$, lobatomide- $\mathrm{B}(\mathrm{I} \mu \mathrm{M})$ or salicylihalamide- $\mathrm{A}(\mathrm{I} \mu \mathrm{M})$ for one hour prior to cerulein $100 \mathrm{nM}$ treatment for an additional hour. Cells were then embedded and assessed for cytosolic vacuole formation and membrane blebbing. Arrows indicate membrane blebbing and arrowheads indicate vacuoles. Images were taken at $40 \times$ magnification and are representative of each treatment group.

Abbreviations: A, control; B, cerulein $100 \mathrm{nM}$; C, cerulein + concanamycin; D, cerulein + lobatomide; $\mathrm{E}$, cerulein + salicylihalamide. 


\section{Disclosure}

The author reports no conflicts of interest in this work. The authors would like to thank Christine Shugrue for her critical reading of this manuscript and Shao Song for expert technical assistance.

\section{References}

1. Leach SD, BilchikAJ, Karapetian O, Gorelick FS, Modlin IM. Influence of chloroquine on diet-induced pancreatitis. Pancreas. 1993;8(1):64-69.

2. Waterford SD, Kolodecik TR, Thrower EC, Gorelick FS. Vacuolar ATPase regulates zymogen activation in pancreatic acini. J Biol Chem. 2005;280(7):5430-5434

3. Smardon AM, Tarsio M, Kane PM. The RAVE complex is essential for stable assembly of the yeast V-ATPase. J Biol Chem. 2002;277(16):13831-13839.

4. Huss M, Ingenhorst G, Konig S, et al. Concanamycin A, the specific inhibitor of V-ATPases, binds to the Vo subunit c. J Biol Chem. 2002;277(43):40544-40548.

5. Bowman BJ, McCall ME, Baertsch R, Bowman EJ. A model for the proteolipid ring and bafilomycin/concanamycin-binding site in the vacuolar ATPase of Neurospora crassa. J Biol Chem. 2006;281(42):31885-31893.

6. Teplova VV, Tonshin AA, Grigoriev PA, Saris NE, Salkinoja-Salonen MS. Bafilomycin A1 is a potassium ionophore that impairs mitochondrial functions. J Bioenerg Biomembr. 2007;39(4):321-329.

7. Hong J, Nakano Y, Yokomakura A, et al. Nitric oxide production by the vacuolar-type $(\mathrm{H}+)$-ATPase inhibitors bafilomycin A1 and concanamycin A and its possible role in apoptosis in RAW 264.7 cells J Pharmacol Exp Ther. 2006;319(2):672-681.

8. Shacka JJ, Klocke BJ, Shibata M, et al. Bafilomycin A1 inhibits chloroquine-induced death of cerebellar granule neurons. Mol Pharmacol. 2006;69(4):1125-1136.

9. Shacka JJ, Klocke BJ, Roth KA. Autophagy, bafilomycin and cell death: the "a-B-cs" of plecomacrolide-induced neuroprotection. Autophagy. 2006;2(3):228-230.

10. Boyd MR, Farina C, Belfiore P, et al. Discovery of a novel antitumor benzolactone enamide class that selectively inhibits mammalian vacuolar-type (H+)-ATPases. J Pharmacol Exp Ther. 2001;297(1):114-120.

11. Huss M, Sasse F, Kunze B, et al. Archazolid and apicularen: novel specific V-ATPase inhibitors. BMC Biochem. 2005;6:13.

12. Galinis DL, McKee TC, Pannell LK, Cardellina JH, Boyd MR. Lobatamides A and B, novel cytotoxic macrolides from the tunicate Aplidium lobatum. J Org Chem. 1997;62(26):8968-8969.

13. Erickson KL, Beutler JA, Cardellina JH, Boyd MR. Salicylihalamides A and B, novel cytotoxic macrolides from the marine sponge Haliclona sp. J Org Chem. 1997;62(23):8188-8192.

14. Xie XS, Padron D, Liao X, Wang J, Roth MG, De Brabander JK. Salicylihalamide A inhibits the V0 sector of the V-ATPase through a mechanism distinct from bafilomycin A1. J Biol Chem. 2004;279(19):19755-19763.

15. Lu Z, Karne S, Kolodecik T, Gorelick FS. Alcohols enhance caeruleininduced zymogen activation in pancreatic acinar cells. Am J Physiol Gastrointest Liver Physiol. 2002;282(3):G501-G507.

16. Bijlsma PB, Kiliaan AJ, Scholten G, Heyman M, Groot JA, Taminiau JA. Carbachol, but not forskolin, increases mucosal-to-serosal transport of intact protein in rat ileum in vitro. Am J Physiol Gastrointest Liver Physiol. 1996;271(1):G147-G155.

Open Access Animal Physiology

\section{Publish your work in this journal}

Open Access Animal Physiology is an international, peer-reviewed, open access journal publishing original research, reports, reviews and commentaries on all areas of animal physiology. The manuscript management system is completely online and includes a very
17. Kiliaan AJ, Scholten G, Bijlsma PB, Dekker K, Groot JA. Influence of forskolin and carbachol on intestinal absorption of horseradish peroxidase in the goldfish (Carassius auratus). Cell Tissue Res. 1996;285(1):51-56.

18. Chaudhuri A, Kolodecik TR, Gorelick FS. Effects of increased intracellular cAMP on carbachol-stimulated zymogen activation, secretion, and injury in the pancreatic acinar cell. Am J Physiol Gastrointest Liver Physiol. 2005;288(2):G235-G243.

19. Li C, Chen X, Williams JA. Regulation of CCK-induced amylase release by PKC-\{delta $\}$ in rat pancreatic acinar cells. Am J Physiol Gastrointest Liver Physiol. 2004;287(4):G764-G771.

20. Chen X, Edwards JAS, Logsdon CD, Ernst SA, Williams JA. Dominant negative Rab3D inhibits amylase release from mouse pancreatic acini. J Biol Chem. 2002;277(20):18002-18009.

21. Hall PA, Lemoine NR. Rapid acinar to ductal transdifferentiation in cultured human exocrine pancreas. J Pathol. 1992;166(2):97-103.

22. Forgac M. Vacuolar ATPases: rotary proton pumps in physiology and pathophysiology. Nat Rev Mol Cell Biol. 2007;8(11):917-929.

23. Bhoomagoud M, Jung T, Atladottir J, et al. Reducing extracellular $\mathrm{pH}$ sensitizes the acinar cell to secretagogue-induced pancreatitis responses in rats. Gastroenterology. 2009;137(3):1083-1092.

24. Figarella C, Miszczuk-Jamska B, Barrett A. Possible lysosomal activation of pancreatic zymogens. Activation of both human trypsinogens by cathepsin B and spontaneous acid. Activation of human trypsinogen 1. Biol Chem Hoppe Seyler. 1988;369:293-298.

25. Greenbaum L, Hirshkowitz A. Endogenous cathepsin activaties trypsinogen in extracts of dog pancreas. Proc Soc Exp Biol Med. 1961;107:74-76.

26. Kukor Z, Mayerle J, Kruger B, et al. Presence of cathepsin B in the human pancreatic secretory pathway and its role in trypsinogen activation during hereditary pancreatitis. J Biol Chem. 2002;277(24):21389-21396.

27. Tooze J, Hollinshead M, Hensel G, Kern H, Hoflack B. Regulated secretion of mature cathepsin B from rat exocrine pancreatic cells. Eur J Cell Biol. 1991;56(2):187-200.

28. Willemer S, Bialek R, Adler G. Localization of lysosomal and digestive enzymes in cytoplasmic vacuoles in caerulein-pancreatitis. Histochemistry. 1990;94(2):161-170.

29. Grady T, Mah'Moud M, Otani T, Rhee S, Lerch MM, Gorelick FS. Zymogen proteolysis within the pancreatic acinar cell is associated with cellular injury. Am J Physiol. 1998;275(5 Pt 1):G1010-G1017.

30. Otani T, Chepilko SM, Grendell JH, Gorelick FS. Codistribution of TAP and the granule membrane protein GRAMP-92 in rat caerulein-induced pancreatitis. Am J Physiol. 1998;275(5 Pt 1):G999-G1009.

31. Hofbauer B, Saluja AK, Lerch MM, et al. Intra-acinar cell activation of trypsinogen during caerulein-induced pancreatitis in rats. Am J Physiol. 1998;275(2 Pt 1):G352-G362.

32. Thrower EC, Diaz de Villalvilla AP, Kolodecik TR, Gorelick FS. Zymogen activation in a reconstituted pancreatic acinar cell system. Am J Physiol Gastrointest Liver Physiol. 2006;290(5):G894-G902.

33. Thrower EC, Osgood S, Shugrue CA, et al. The novel protein kinase C isoforms -delta and -epsilon modulate caerulein-induced zymogen activation in pancreatic acinar cells. Am J Physiol Gastrointest Liver Physiol. 2008;294(6):G1344-1353.

34. Ji B, Gaiser S, Chen X, Ernst SA, Logsdon CD. Intracellular trypsin induces pancreatic acinar cell death but not NF-kappaB activation. J Biol Chem. 2009;284(26):17488-17498.

\section{Dovepress}

quick and fair peer-review system. Visit http://www.dovepress.com/ testimonials.php to read real quotes from published authors. 